\title{
The Value of Javanese Philosophy in Society as a Form of Mass Communication in the Context of the Implementation Element of Covid 19 Handling and SDGs
}

\author{
Surahmadi1, Endro Tri Susdarwono2 \\ 1. 2Ilmu Komunikasi, FISIP, Universitas Peradaban \\ 1midas999saniscara@gmail.com
}

\begin{abstract}
ABSTRAK
Tujuan penelitian ini hendak mengangkat tentang nilai-nilai yang ada dalam falsafah jawa utamanya yang terkomunikasikan massa dalam akar masyarakat sebagai modal implementasi kebijakan penangan covid 19 dan SDGs. Penelitian ini merupakan penelitian kualitatif, tipe penelitiannya menggunakan kajian komprehensif analitis dan pendekatannya normatif analitis. Saluran (channel) komunikasi massa dalam menanamkan nilainilai falsafah jawa ke akar masyarakat melalui berbagai macam saluran, salah satu yang mampu menarik massa melalui pementasan wayang. Makna di balik pementasan wayang adalah sebuah tontonan yang berfungsi sebagai hiburan sekaligus menjadi gambaran dan tuntunan kehidupan. Saluran (channel) lain yang merupakan proses komunikasi massa juga didapati dalam ajaran baik yang tertulis maupun tidak tertulis. Nilainilai falsafah Jawa yang tertanam dalam akar masyarakat merupakan modal berharga yang digunakan dalam implementasi penanganan covid 19 dan pelaksanaan SDGs karena nilai-nilai tersebut sangat sesuai dan sudah berakar lama alam praktik kehidupan keseharian masyarakat. Hanya dibutuhkan kembali suatu kebijakan untuk menghidupkan nilai-nilai falsafah Jawa tersebut sehingga bisa diimplementasikan sebagai kebijakan penangan covid 19 dan pelaksanaan SDGs.
\end{abstract}

Kata kunci: covid 19; filsafat Jawa; komunikasi massa; SDGs

\begin{abstract}
The purpose of this study is to raise the values that exist in the main Javanese philosophy which is communicated by the masses in the roots of society as the capital of implementing Covid 19 and SDGs. This research is a qualitative research, the type of research uses a comprehensive analytical study and analytical normative approach. Channels of mass communication in instilling the values of Javanese philosophy into the roots of society through a variety of channels, one of which is able to attract the masses through puppet performances. The meaning behind the puppet show is a spectacle that serves as entertainment as well as being a picture and guide of life. Other channels which are a process of mass communication are also found in both written and unwritten teachings. Javanese philosophical values embedded in the roots of the community are valuable capital used in the implementation of covid 19 management and implementation of SDGs because these values are very appropriate and have long rooted in the practice of people's daily lives. Only a policy is needed to revive the values of Javanese philosophy so that it can be implemented as a covid handler 19 policy and SDGs implementation.
\end{abstract}

Keywords: covid 19; Javanese philosophy; mass communication; SDGs

\section{INTRODUCTION}

Indonesian culture shows a more human urge. The historical culture of Indonesia shows a pattern of direction toward spiritual encouragement. Puppet, as one of the results of Indonesian native culture, shows that spiritual pattern. In the world of art, whatever its form, it has at least eight very important social functions. The social function expansiveness is a means of art, a means of relaxing entertainment, a means of identity statement of integrative or intermingling means, a means of therapy or healing, a means of education, a means of restoring order, and a symbolic means containing magical powers and rituals (Kresna, 2012, p. 18 -19). 
Human life also seems to be inseparable from the symbolism or bridging in bridging things that are not yet understood. One important symbol that is in direct contact with the gates of Javanese human life, in particular is wayang. All kinds related to wayang, ranging from scenes and plays, shadow puppets, stage equipment (blencong, beber, etc.), time sharing, and row of puppets on the left and right sides of the screen (banana stems to stick puppets), all have important meaning saying for unknown and preserved (Kresna, 2012, p. 17-18)

According to Socrates, people only do evil because they do not know what is really good for them. The virtue is a matter of knowledge, and if a person is taught what is really good for him, then he will act according to that virtue. The virtues are like the lonely attitude of self-respecting rame ing gawe. Our actions are appropriate if we support harmony if we can occupy our place in the whole in harmony. But an action that disturbs harmony, which results in crippling, disquiet and confusion in society is wrong (Rachmatullah, 2010, p. V).

The description of the Jendra Literature contains teachings for Narendra (King) or Kahendra (gods) to be able to make the world clean of Hayuningrat and be able to ward off or ward off evil or Dyu, it is called pangruwating dyu. Good teachings must still be done to balance the evil that always arises.

The implementation of Jendra Literature by humans is manifested by behavior, which is based on thoughts, feelings and actions (copyright, taste, intention) as outlined in the upload section, as a code of conduct for life. With this uploading behavior, it is expected that Indonesian people and the younger generation will find a way of peace, peace and prosperity. Realizing that life is a gift, a calling and a duty to proclaim goodness (Werdoyo, 2013, p. Xix).

The teachings of Mangkunegara I are known as Tri Dharma namely rumangsa melu handarbeni, rumangsa melu angrungkebi, mulat sarira angrasa wani that requires the active participation of the people directly in the administration of the state. Elitism in an organization should be avoided by leaders (Hendri, 2008, p. 23). Tri Dharma consists of Mulat sarira Hangrasa Wani (know yourself and be strong and smart, Rumangsa Melu handarbeni (think that state property is yours) and Rumangsa Melu Hangrungkebi (obligation to be ready to defend the country). These three principles then manifest as a major ideology for you all citizens of Indonesia. As a citizen it is clearly obligatory to recognize themselves and explore their potential, then all of these potentials must be placed on the basis of a sense of togetherness in having an Indonesian state.

Efforts to prevent the spread of the virus include travel restrictions, quarantine, curfew, hazard control at work, event delays and cancellations, and facility closures. These include Hubei quarantine, national or regional quarantine elsewhere in the world, curfew actions in China and South Korea, various border closures or restrictions on incoming passengers, screening at airports and train stations, and restrictions on the travel of departing passengers.

The pandemic has caused severe global socio-economic disruption, postponement or cancellation of sporting, religious and cultural events, and widespread fears of supply shortages have prompted panic purchases. Schools and universities have been closed either nationally or locally in more than 160 countries, affecting more than 1.5 billion students. False information and conspiracy theories about the virus have spread online and there have been incidents of xenophobia and racism against the Chinese, and other East and Southeast Asians. When pandemics spread and hotspots formed around the world, such as in Europe and the United States, discrimination against people from these hotspots also occurred.

Sustainable Development Goals (SDGs) are a global action plan agreed by world leaders, including Indonesia, to end poverty, reduce inequality and protect the environment. The SDGs contain 17 Objectives and 169 Targets that are expected to be achieved by 2030. Therefore, SDGs are presented with the 2015-2030 period which is expected to be able to change the world to be even better with 17 general objectives that can be implemented by each country.

All people in the country must play a role in realizing sustainable development. Sustainable development is a way for the community to increase development without creating side effects from the development, and keep thinking that non-renewable energy has decreased. With small things like this, it is hoped that we, as successors to the nation, can reduce the corruption that is at the root of the 
economic problems in Indonesia. With all our heart and pride being the people of Indonesia must realize that the fate and development of the nation is in our hands and development does not only depend on the government. Therefore, we must continue to strive to become a society that can create good change and is certainly beneficial for the Indonesian homeland. Face difficulties, enjoy prosperity!

The purpose of this study is to raise the values that exist in the main Javanese philosophy which is communicated by the masses in the roots of society as the capital of implementing Covid 19 and SDGs.

\section{METHODS}

The method is a way of working to be able to understand an object. The research method is a way of working to understand the object of research (a collection of methods is called methodical, whereas the study of methods is called methodology). Discussing the methodology will also reveal techniques: data collection or how to obtain data, how to determine samples, data analysis, variables and sub variables involved, or statistical formulas used. Each type of research will use data collection methods and techniques that are compatible with this type of research. While the technique is defined as a working tool which is a completeness of how to obtain data or information.

The scientific method used for research is called the research methodology. The method is a way of working to be able to understand the object of research. In addition to the method also known as research techniques, the technique is defined as a working tool which is a complete way of working (methods). Actually the technique is included in the method, which when viewed in terms of its implementation. The method as a working tool is more emphasized on the workings of the mind in order to understand the object of research. Technique is seen as a way of working to do or capture the workings of the mind.

\section{Approach Method}

In contrast to the positivistic approach, the qualitative method adopts what is called an ontological view - the recognition that reality is not objective. If related to Devine's comments that have been mentioned that researchers need to enter the social setting of the focus of research - we can begin to understand that context is the main aspect behind quality research: what we actually seek answers to is not only "what happened", but also "Why" and "how" (Harrison, 2007, p. 89).

This type of research uses qualitative type, in which the most important qualitative research is how to determine key informants who are full of information in accordance with the focus of the study. Qualitative methods can be used to uncover and understand something behind phenomena that are not yet known. This method can also be used to get information about something that should be little known, and can help researchers provide complex details about phenomena that are difficult to express by quantitative methods. Qualitative descriptive format aims to describe, summarize the various conditions, situations or various phenomena of social reality in society that are the object of research and try to pull that reality to the surface as a character trait, trait, model, sign or picture of the condition, situation, or certain phenomena.

\section{Research Specifications}

Soerjono Soekanto sees in terms of "the nature of research", he distinguishes it into 3 (three) types, namely exploratory research, descriptive research, and explanatory research. Whereas in terms of "research objectives", J. Vredenbregt distinguishes social research into 3 (three) types, namely exploratory research, descriptive research, and explanatory research (Muhammad, 2004, p. 52). The research specifications in this study use descriptive qualitative.

\section{Method of collecting data}

Data collection is a systematic procedure for collecting data needed in a study. There is always a relationship between data collection methods and the problem under study. For data retrieval, we need a data collection tool, commonly called an instrument (data collector) or a collection tool. Types of collection methods, namely:

a. bibliography study 
Data collection is carried out with a literature study covering sources relevant to the problem; transcript records, books, newspapers, magazines, agendas, archives, and other literature. Literature study is carried out through the stages of identifying the data source library, identifying the materials needed, and inventorying the materials (data) needed. Data that has been collected is then processed through the stages of inspection (editing), marking (coding), compilation (reconstructing), systematization based on the subject matter and sub-topics identified from the problem formulation (systematizing).

b. document study

Documentation is carried out to obtain data by utilizing secondary data that is already available or processed. This secondary data includes official government organization documents and other institutional documents.

\section{Technical Analysis}

Data analysis (analyzing), which describes data in the form of sentences that are good and right, so that it is easy to read and be given meaning (interpreted) so that the results of data analysis make it easier to draw conclusions inductively. Data analysis is a technique for analyzing various kinds of data found and obtained by researchers in the field, whether the data is obtained from observations or observations directly to the object under study or obtained from the study of documents found. Then the data obtained was linked and linked to the main problems that exist.

According to Miles and Huberman data analysis is an activity that refers to a systematic review or testing of a matter in order to determine the parts, the relationship between parts and relationships in a whole. These activities are carried out simultaneously and intertwine between data reduction and drawing conclusions or verification, starting with data collection and giving feedback on data collection. There are three main elements in the process of data analysis in qualitative research, namely:

1. Data reduction

Data reduction is part of the analysis process, which is a form of analysis to reinforce, shorten, focus, discard unnecessary things and organize data, so conclusions can be drawn. This data reduction process continues throughout the implementation of research, in the form of abbreviations, making code, focusing themes, creating boundaries of problems and writing memos.

2. Data presentation

The data presentation is an arrangement of information that enables the conclusion of a research. By seeing this data presentation, researchers will understand what is happening and provide opportunities for researchers to do something to the analyst or other actions based on his understanding. Presentation of data in the form of image matrices, schematics, networks, work and tables may help to analyze in order to get a clear picture and make it easier to draw up research conclusions. Basically, the data presentation is designed to describe information systematically and is easily seen and understood in the overall form.

3. Withdrawal of Conclusions

Since the beginning of data collection researchers must have begun to understand the meaning of things encountered by noting regularities, patterns, statements of various possible configurations, the direction of causal relationships and propositions. Final conclusions on qualitative research will not be drawn unless, after the data collection process ends. Conclusions made need to be verified by looking and questioning again, while glancing at the field notes to get a more accurate understanding.

In this study the authors used data analysis techniques with qualitative descriptive analysis strategy models. This analysis analysis model can provide an overview of the logic of data analysis in qualitative research while providing input on how qualitative data analysis techniques are used. This analysis does not cover itself with the use of quantitative data, even the use of quantitative data is useful for the development of qualitative data analysis itself.

\section{RESULTS AND DISCUSSION}

The Value of Javanese Philosophy in Society as a Form of Mass Communication 
Communication is the process of operating a stimulus (stimulus) in the form of symbols or symbols of language or motion (nonverbal), to influence the behavior of others. These stimuli or stimuli can be in the form of sounds / gifts or spoken language, or in the form of movements, actions, or symbols that are expected to be understood by other parties, and the other party responds or reacts in accordance with the intention of the party providing the stimulus. Therefore the reaction or response, both in the form of language and symbols, is an influence or result of the communication process. The communication process that uses stimulus or response in the form of language, both oral and written, hereinafter referred to as verbal communication. Meanwhile, if the communication process uses symbols called nonverbal communication. (pg 67)

In order for effective communication between one party to another, between one group to another, or someone with another person, it requires the involvement of several elements of communication, namely: communicators, communicants, messages, and channels or media.

a. source:

Is a person or source that conveys or issues a stimulus, among others in the form of: information, or more accurately called messages that must be delivered to another party or person, and it is hoped that the person or other party will provide a response or answer. If the other person or other party does not provide a response or answer, it means that there is no communication between the two variables.

b. receiver:

The communicant is the party who receives the stimulus and responds to the stimulus. The response can be passive, that is, understanding or understanding what is meant by the communicant or in active form in the form of expressions through the discussion of the verbal or written (verbal) or using symbols (nonverbal). Just accepting a stimulus without responding has not yet occurred the communication process.

c. message:

Is the contents of the stimulus issued by the communicator (source) to the communicator (receiver). The contents of the stimulus in the form of messages or information issued by the communicant is not just received or understood by the communicant but is expected to be responded positively and actively in the form of behavior or action.

d. media:

Channels or more popularly called the media are tools or means used by the communicant in conveying messages or information to the communicant. The types and forms of communication channels or media vary greatly, starting from the most traditional ones through mouth (oral), sounds (kentongan), writing (prints) to the most modern electronics, namely television and the internet (Notoatmodjo, 2010, p.67-69) 


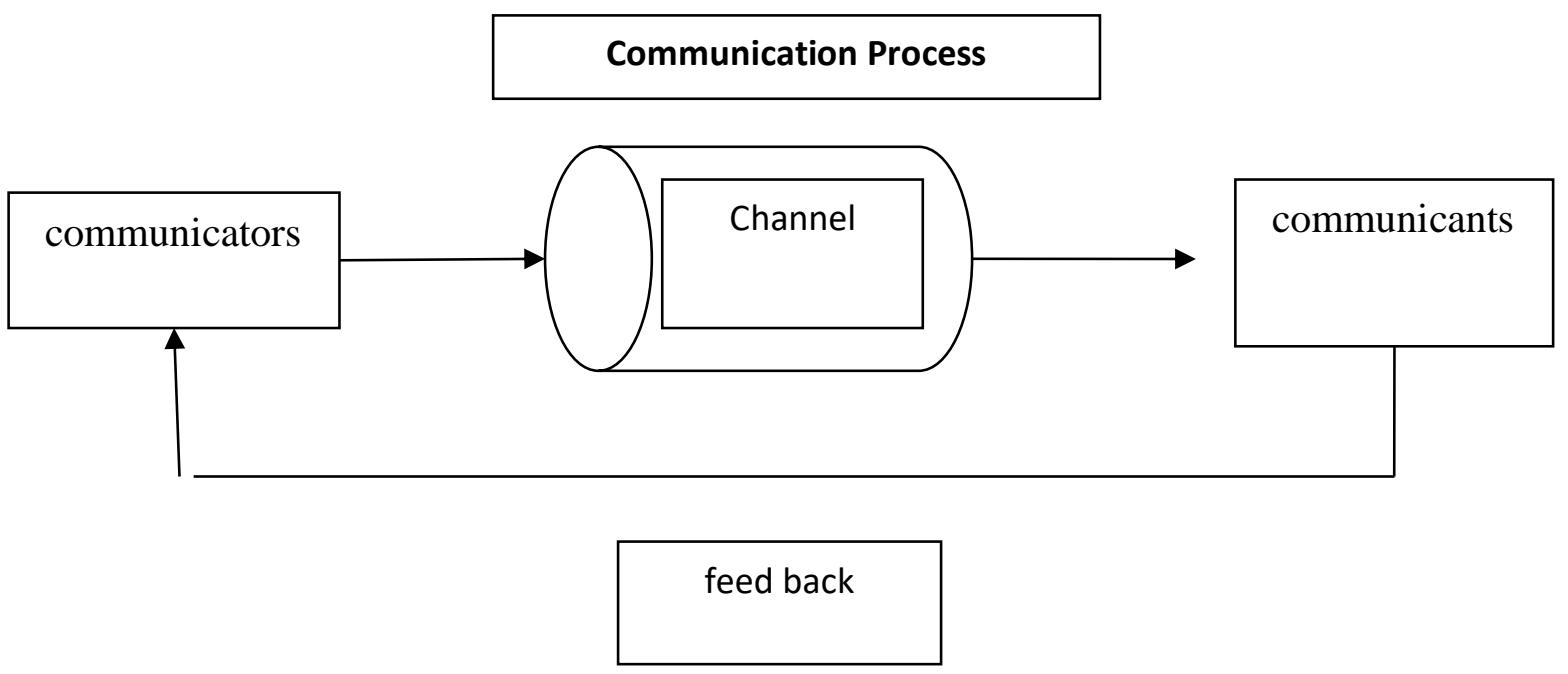

Figure 1. The process of communicating with Soekidjo Notoatmodjo

Channels of mass communication in instilling the values of Javanese philosophy into the roots of society through a variety of channels, one of which is able to attract the masses through puppet performances. The meaning behind the puppet show is a spectacle that serves as entertainment as well as being a picture and guide of life. Aside from being an entertaining spectacle, wayang art also holds philosophical meanings that sometimes appeal to the mystical world.

The role of the puppeteer in the wayang is to arrange the course of a story. Without a puppeteer, a puppet would never be able to walk. Puppeteer is a parable of traditional, spiritual, governmental leaders, family heads, and so on. This is an appreciation that in fact all God's creations on earth would never have been able to run without the khalifah (leader) who always showed the course of life (Kresna, 2012, p. 19).

Beber (white screen without spot), is a depiction of the origin of the sacred earth before it was inhabited by any creature. However, when the creature has entered the beber, then the earth will automatically be contaminated by the characteristics of the creature itself. That is what will make a subjective assessment of black bmi or black and white valleys. But at the end of the story, some will be white again. This likens that someday, even creatures are destroyed from the earth (Kresna, 2012, p. 20). Kelir (banana tree trunk) is a depiction of a body inhabited by a soul in the form of a puppet. The color will not be useful without the puppet being plugged in. The screen is only used when the puppet is put on a beber. When the puppet is not laid, the screen will be thrown into the trash. The philosophical value, the body will only be useful when the soul is still stuck.

Puppets, in their manufacture, are of various shapes. Some are good, some are scary, and some are funny. However, when it is performed, wayang has two points of view. First, the puppet shown is a mere shadow (shadow), and secondly, the original puppet is held by the puppeteer. This likens the soul of beings who always have two different dimensions. Some are exhibited to creatures and some are not (sirri), but are always held by the mastermind (Kresna, 2012, p. 20-21). Blencong (lights in front of the screen), likens the light (revelation) of life. Without blencong, the puppet will not be able to walk even though it has been stuck on the screen. Similarly, without the light of life, the body and soul of any creature will not be able to live. And, the light (revelation) of life belongs only to Sang Hyang Murbaning Dumadi (Allah).

The crates or puppets function for storing puppets, both those that have not been used or those that have died. This likens a grave to figures who are already dead. Even though we live like anything else, we will eventually be locked in a dark, narrow and stuffy place.

In staging puppets, plays, and story lines can not be done by the puppeteer, but must go through several considerations, for example, people's trust in the staging place and the purpose of the performance itself (ruwatan, larung, or perhaps also the instigation of the respondent or puppeteer) . 
Other channels which are a process of mass communication are also found in both written and unwritten teachings. Teachings in the form of kawruh or also called literature in the past were given orally or in the form of stories or fables. The teaching is called kawruh story or known as carita literature (Werdoyo, 2013, p. Xvi-xvii). From Literature Stories then change due to human progress with pictures or writings, so that literature which was only in the form of fairy tales oral stories has been made even easier. through pictures such as contained in Wayang Beber or reliefs in temples. In addition to the picture also in the form of writing, fiber, kakawin, chronicle, suluk and so on so called Tinulis Literature.

From this literary literature began to open teachings given and used for the provision of social life, the next development was made books produced by historical scavengers, ajran scavengers, which had been written on rocks, leaves, or cave walls so that from literary literature became Literature Cetha From this beginning people see that knowledge becomes a source of knowledge that continues to be developed so that it becomes knowledge (Werdoyo, 2013, p. Xviii). The seseph teach by through: parables, symbols, figures of speech, symbols and so on. The knowledge is delivered personally, certain people, or certain groups and is still confidential and in the form of stories, advice, messages. If it is conveyed to many people it is still in the form of sanepa or parable so that it is disguised, it still takes the form of a closed teaching (secret), so that many terms that seem to be beautiful are interesting to look for the meaning of a sentence or words (Werdoyo, 2013, p. 20).

The following are the values of Javanese philosophy communicated by the masses and become a handle in the roots of society that can be used as a model in implementing the handling of Covid 19 and SDGs. 


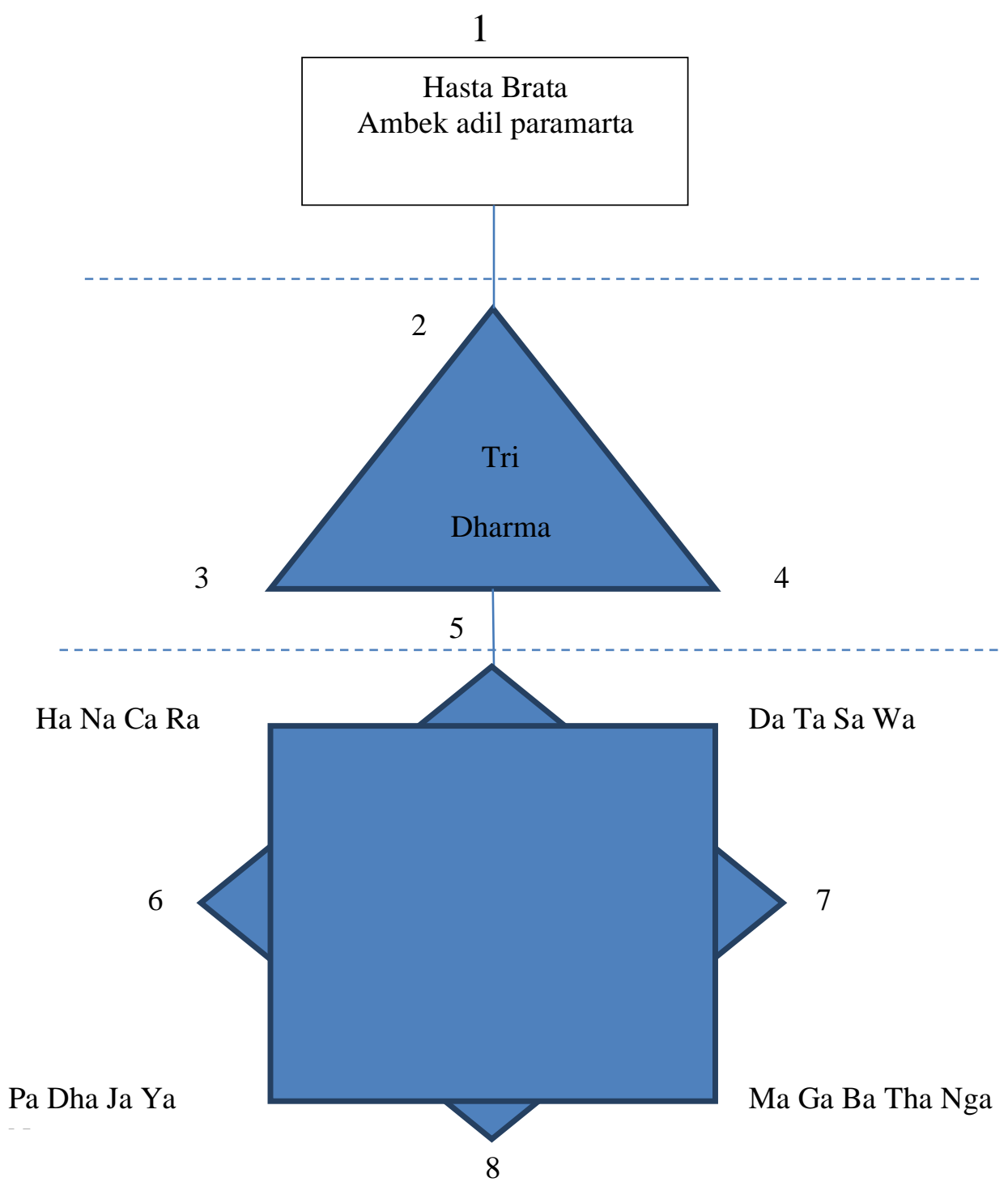

Figure 2. Javanese Philosophy Values Communicated by the Mass in the Community

\section{Hastha Brata}

The concept of Astabratha requires that a leader has the characteristic of ambarta fair paramarta or fair character evenly without favoritism.

1. Ambeging bumi, tansah adedana, karem ambebungah marang jalma, danane dene tetuwuhan kang cukul ing awake, sukalila den alap ing jalma. Ajaa tetuwuhane yen ora lilaha, najan badane dewe den duduki den paculi, lega lila ora nduweni sak serik, malah yen kabeneran bisa ngatonake pendemane rajabrana, dadi kabungahane kang anduduk.

First, the nature of the earth is a symbol of the generosity of a leader who is always giving to others, selflessly providing whatever is needed for people who live under his imagination.

2. Ambeging banyu, anggelarake apura para marta, bisa angenaki ati, nora rengatan, cinibukan pulih ora ana labete.

Second, fire is a symbol of energy and strength. The constructive spirit of fire that must be possessed by leaders, among others, is in the form of the ability or courage to burn or eliminate the things that hinder the dynamics of national and state life, for example ifat angkara anger, greedy, vile, vile, corrupt, destructive and others. 
3. Ambeging agni, amisesa ing kalesa, bisa anglebur reregeding bumi, ambabadi kang arungkud, amadangi kang apeteng, yen kalonglongan nora suda atine, bisa sareh bisa sereng nora kawistara lakune.

Third, water / banyu is a character that describes a leader must always flow dynamically and have a humble character, andhap asor and polite, leaders must be fair in carrying out policies related to the lives of many people. Water also gives life to all living things on earth, which means the leader must have concern for the preservation of the environment, managing nature for the benefit of Together in wise and wise ways.

4. Ambeging angin, tan pegat titipariksa, anggung anginjen-injen solahing jalma, bisa nuksma ing agal-alit, amiguna ing ngaguna, lakune tanpa wangenan, pamrihe tanpa tengeran, yen katulak ora esak, yen katarik nora serik.

Fourth, the character of the wind or air, the character that gives the right to life to the community. The right to life includes the right to a decent life (clothing, food, shelter and health), self-development, obtaining a source of life (work), opinion and association, and developing culture.

5. Ambeging surya, sareh ing karsa, rereh ing pangarah, nora daya-daya antuka sabarang kang den pe ing panasing srengenge, nora age-age den garingake, lakune angarah-arah patrape angirih-irih, pamrihe ing sabarang reh yen rereh nora rekasa anggone amisesa.

Fifth, Surya or sun is a symbol that the leader must be able to be the light of life as well as an energy provider of community life. Leaders must be intelligent, able to provide clarity about the situations and conditions that actually occur in society while offering the best alternative solutions among the various options that might be available.

6. Ambeging rembulan, bisa anugraha amet prana, sumeh ing netya alus ing budi, anawuraken raras-rum, sumrah sumarambah marang aisining jagad.

Sixth, the character of the moon / candra. As the moon has softness to calm, the wise leader always gives a sense of peace and becomes a ray in the dark. He must be able to lead with a variety of wisdom as well as visionary. The moon also signifies the cycle and rotation that has to eat a leader must be willing to step down and be replaced with new leaders who are truly able to develop the people's mandate and be able to take responsibility before God and humans.

7. Ambeging lintang, santosa pengkuh nora keguhan, nora leres ing ubaya, nora lelemeran ing karsa pitayan-aten tanpa samudana.

Seventh, star or Kartika. Bintang is a guide symbol for travelers and fishermen who are in the middle of a wide ocean. Leaders must be able to be orientation and role models while at the same time able to explore people's feelings.

8. Ambeging mendung, angempakake dana wesiyasat, adil nora nganggo baukapine, danane yen kebeneran aweh ganjaran anurunake udan; wesiyasane yen ana kang kaluputan pinidana ing Guntur tanpa pasesa, adile agung angawruhi ala becike manungsa, gebyaring kilat kang minangka titipariksane, kang ala nemu paikuman, kang becik antuk ganjaran. (Supardi, 1961, p. 24)

Eighth, the nature of the sky or the sky. With this character, the leader must have a broad heart, feelings, and thoughts in dealing with various problems of the nation and state. The sky also symbolizes that a leader must not panic in facing any situation, remain calm even though he is carrying a very heavy burden, but must always be vigilant and run the government with full responsibility.

\section{Tri Dharma Mulat sarira hangrasa wani}

Get to know yourself and be strong and smart

3. Tri Dharma Rumangsa melu handarbeni

Assume that state property is yours.

4. Tri Dharma wajib melu hangrungkebi

The obligation to be ready to defend the country.

\section{Mulat sarira dan introspeksi}

Mulat sarira means more introspective, introspection and alert to all the temptations and dangers that will plunge human life. Always pay attention to the movements and steps of human life. 
Always pay attention to the movements and steps of life that we meet so as not to deviate from the teachings of truth that we believe so far both from moral teachings, ethics, law and religion.

Mulat sarira, teaches to always introspect yourself. "What am I? Who am I? Where am I going to go? Why am I there? " Awareness to always reflect on oneself will give birth to the right character, empathize continuously to fellow human beings. Individual freedom will end when the other individual also wishes or feels free. Then the understanding of mulat sarira and tepa selira is an eternal to every individual who preaches freedom in living together.

\section{Mikul dhuwur mendhem jero}

Although intended to always respect parents and leaders, but do not blind yourself to assess the actions of parents and leaders. Because the elderly and leaders also have the same obligation to always do the right thing, good and right. In fact, the elderly and leaders are demanded to be more in actualizing noble character. Parents who do not have nobility are called tuwa tuwas lir sepah samun. Parents who have no use and meaning that are not worthy of being followed. Leaders who do not have nobility are also not leaders.

\section{Jangan jadi "Katak dalam Temurung}

The principle "it's better not to do anything than to make mistakes" must be reversed to "it's better to try and do wrong than not doing anything." Because mistakes and failures in every effort we make will lead us to understand "what" and "why" we failed in previous attempts. In addition, by trying and doing new things we will gain knowledge, insight, and new ways to deal with this complex and complex world.

\section{Perubahan adalah keniscayaan}

Water has characteristics and characteristics that distinguish it from other objects. Likewise it should be with us. In the changes and the continuous flow of life, our character, personality, personality, and characteristics as individuals do not have to be lost but must be maintained. The uniqueness and differences that exist will ultimately enrich our relationship with others. We can learn from others, and vice versa. However, many people are not willing to listen to others because they already feel right, smart and Mumuni. Though this attitude will only narrow our views and insights about life itself.

\section{Ha Na Ca Ra Ka}

Ha berarti Hana hurip wening suci "The existence of life is the will of the Glorious One."

Na berarti Nur candar, gaib candar, warsitaning Candara. "Man's hope is only always in Divine light" or "Man always hopes for light that comes from Divine light".

Ca berarti cipta wening, cipta mandulu, cipta dadi. "The direction and purpose of life of all beings is the Most Single".

Ra adalah rasaingsun handulusih. "True love arises from the love of conscience."

Ka berarti karasaningsun memau hayuning bawana. "Desires, desires and intentions are directed towards the welfare and beauty of nature."

\section{Da Ta Sa Wa La}

Da berarti dumadining dzat kang tanpa winangenan. "Accept life as it is, not made up, not adventurous or acting strangely."

Ta adalah tatas, tutus, titis, titi lan wibawa. "Fundamental, sincere, earnestly full of totality, one vision, and have the precision and carefulness in looking at life."

Sa adalah sifat ingsun handulu sifatullah. "Form themselves with the decoration of good qualities possessed by God, such as forgiving, glorifying, and being patient.

Wa adalah wujud hana tan kena kinira. "Human science is limited but the implications can be unlimited."

La adalah lir handaya paseban jati. "That is, flowing life solely at Divine guidance. The ultimate goal of human life is to the Creator, returning to the origin of human creation."

Pa Dha Ja Ya Nya

Pa berarti papan kang tanpa kibalat. "That is, God is the Omniscient Essence, not bound by time and space." 
Dha berarti dhuwur wekasane endek wiwitane. "That is, to be able to above certainly starts from the bottom, from the bottom. In fact, no one can live well without struggle and hard work."

Ja adalah jumbuhing kawula lan Gusti. "If we are "above", do not forget the "below" because before we came from below. Officials and citizens must work together to seek mutual virtue.

Ya adalah yakin marang samubarang tumindak kang dumadi. "The belief that whatever happens in this world, including everything that happens to us is based on the commands and will of God."

Nya adalah nyata tanpa mata, ngerti tanpa diuruki. "Literally, this phrase means "seeing without eyes, understanding without having to be taught" or in short, "understanding the nature of life." A wise person not only learns with the eyes of his birth, but also learns with the eyes of his mind and heart.

\section{Ma Ga Ba Tha Nga}

Ma adalah madep mantep manembah mring Ilahi. That is, worship and serve God without doubt and anxiety, but do it with confidence and faith.

Ga adalah guru sejati sing muruki. That is, learn from real teachers who always teach the truth of conscience and experience.

Ba adalah bayu sejati kang andalani. That is, living people must calculate and consider harmony with nature.

Tha adalah thukul saka niat. That is, everything that is good and beneficial must grow from a sincere and pure intention; intention to improve and glorify our lives and those around us.

Nga adalah ngracut busananing manungso. If humans want to live a noble life and in harmony with natural life, he must let go of his personal egoism.

\section{Implementation of Covid 19 Handlers and SDGs with the Capital of Javanese Philosophy in the Community}

Governance is not only technical agenda of transparency, accountability, participations, and such, as developed by some international development agencies and advisors. Today's most relevant understanding of governance is about the relationship between government and citizens that enable public policies and programs to be formulated, implemented, and evaluated, as noted by Gambhir Bhatta in International Dictionary of Public Management and Governance (2006). Excellent governance is when government succeed in developing: from formulating, implementing and achieving its objectives; excellence public policy. (34).

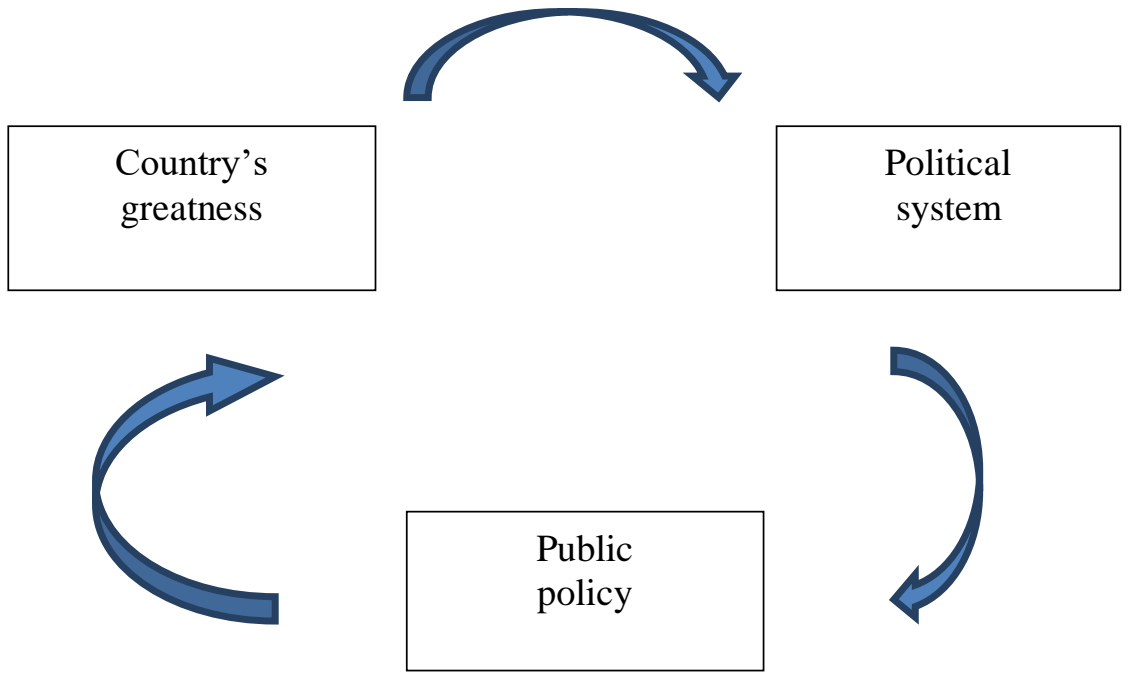

Figure 3. Government and Public Policy

Public policy never emerges in an "empty space". As noted by Kraff and Furlong (2005: 31): "Public policy is not made in vacuum. It is affected by social and economic conditions, prevailing political values and the public mood at any given time, the structure of government, and national and local cultural norms, among other variables" 
Thus, there must be a context that trigger the "birth" of any public policy. The context is a series of process that put public policy at the critical steps. It is believed that society holds goodness as a guidance for their life. The goodness of people is then formally stated in national Constitution (Nugroho, 2012, p. 87).

Public policy is then, is the "rule of the game" which is formalized and legalized by law. The public policy reflects the beliefs on goodness that is again reflected in values and norms applied within political process conducted by political institutions. The challenge is now about how to achieve good or the best policy performance. It is a critical challenge, because the failure of policy performance will determine whether "the belief on goodness" will sustain or change.

Public policy has two level of ecosystem: philosophical or conceptual, and managerial or operational as figured below:

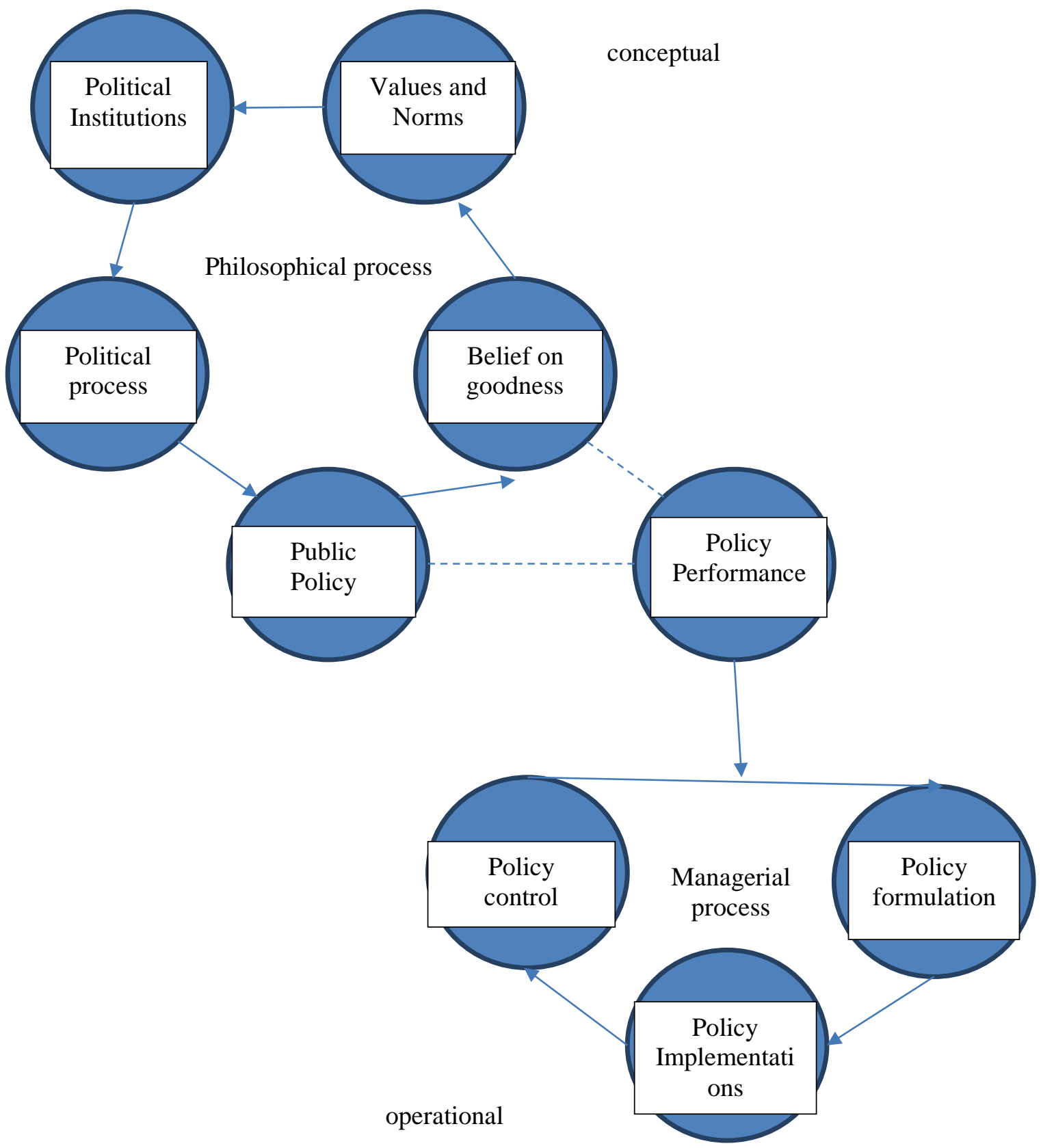

Fifure 4. Two Level Ecosystem of Public Policy 
Javanese philosophy values that have been described above as a form of Philosophical process are expected to be able to be used as capital as an implementation in handling Covid 19 and implementing SDGs. Because these values are actually already embedded in the grass roots of the community, actually how to explore these values for further implementation through managerial or operational processes.

Peter de Leon and Linda de Leon (2001) founded that there are three generations of policy implementations studies. The firs generation, developed in 1970s, understand policy implementation as the discourse between policy and its execution. Graham T. Allison (1971) in his study on Cuban's Missile policy decision and implementation was one of the examples. By this approach, the policy implementation is believed as the later action of the policy decision, at least there is no gap between the policy decision and policy implementation. It was a specific phenomenon of military model of decision making: decide and act.

The second generation which was developed in 1980s believes that the policy implementation is a top-down process, as bureaucratic hierarchical structure or we might call it as the top-downer perspective. The perspective believes that the task of bureaucracy is ti implement any policy which is decided by political institutions and actors. It was understood as Woodrow Wilson's premise: "when politic ends, administration begins". The early study of this approach was Daniel Mazmanian \& Paul Sabatier (1983), Robert Nakamura \& Frank Smallwood (1980), and Paul Berman (1980).

There is a unique emergent theory as a reverse, entitled as the second generation. Whilst the firs generation is "top-downer", the second entrance is "bottom-upper" as studied by Michael Lypski (1971, 1980) and Benny Hjern (1982, 1983). Therefore, in the second generation, there are two contradictory ideas: tow downer and bottom-upper.

The third generation is being developed in 1990s by Malcolm L. Goggin (1990) who promoted idea that the behavior, as variable, of policy implementers more determines the success and the failure of policy implementation. This approach seems to be close to the behavioral theory. Other scholars who develop the same idea are Helen Ingram (1990) and Denise Schebele (1997).

What about in year of 2000? De Leon and De Leon (2001) noted that in 2000s "the study of policy implementation has reached an intellectual dead end". Perhaps it was the wise argument, since the study of policy implementation as performed by Hill and Hupe (2006) has not generated the new approach of policy implementation. How about in this recent years, 2010s? Is the dead end has over?

In regard to my understanding, since 2000s, policy implementation has been growing into more complex model and facts. There are so many disciplines that have been supporting policy implementer by a new and different approach on policy implementation; from political discipline, economic, marketing, physics and mathematics.

It happens until today that the policy implementation, as well as policy studies, becomes the concern of any social science scholars as well as practitioners. Therefore, in today's policy implementation studies and practices, there is a changing from public administration to political domain. It becomes eclectics and keen to be practices rather than rigidly appear as a model promoting the generation of policy implementation as studies. Therefore, I would like to name today's policy implementation model and studies as contextual-conditional model.

In policy implementation studies, there are nine models of policy implementation, model implementasi kebijakan yang digunakan dalam penelitian ini adalah model Nakamura \& Smallwood.

Robert T. Nakamura and Frank Smallwood noted that policy process is a complicated process and implementation.

"The policy process Is complex. Implementation is but one part of this process, and it's inextricably related to, and interdependence with the other parts. Considering implementation without reference to these other parts would be tantamount to studying election return without reference to the personalities of the candidates or the composition of the electorate; only a limited depth of understanding could be attained. Thus, a conceptual overview of the entire policy process is required. One useful way to study the implementation policy is to view the policy process as a system. A system is characterized by a set of interconnected elements, each directly or indirectly related to the other. The utility of a system overview lies in its 
simplification of the policy process into set of element and linkages...The key elements in the policy process can be viewed as a set of functional environments in which different aspects of the process take place. (1980. P. 21)

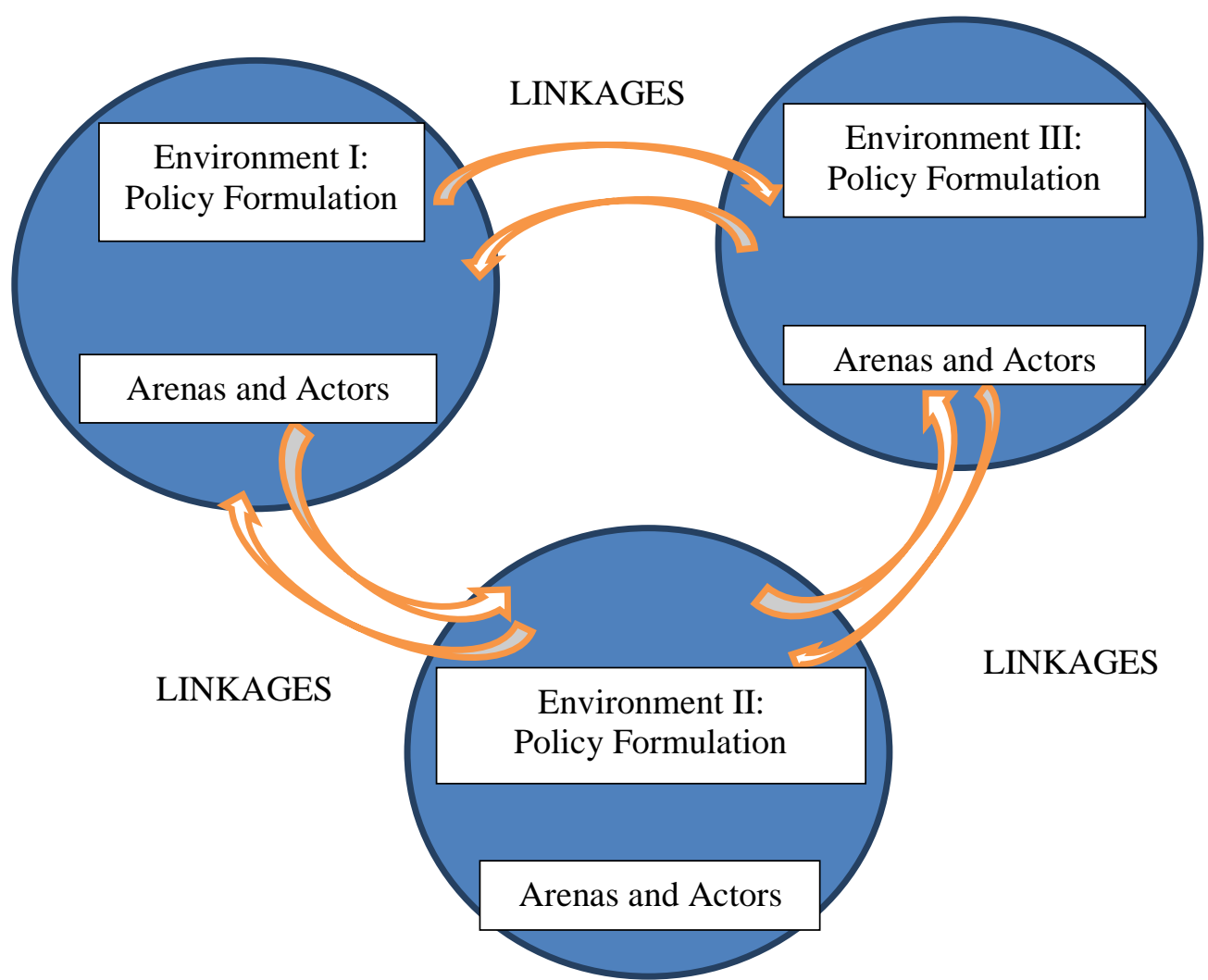

Figure 5. Nakamura \& Smallwood's Model Sumber: Nakamura \& Smallwood (1980)

To deal with the complexity, Nakamura and Smallwood developed policy implementation model which they named as "environments influencing implementation", which consist of three elements with actors and arenas in each ones (Nakamura \& Smallwood, 1980, p. 27).

Environment I: includes how to apply (1. Hasta Brata Ambek fair paramarta). Environment II: includes how to implement Tri Dharma I (2. Tri Dharma Mulat sarira hangrasa wani, 3. Tri Dharma Rumangsa melu handarbeni, 4. Tri Dharma must pass hangrungkebi) Environment III: includes how to apply (6. Mikul dhuwur mendhem jero, 7. Don't be a "Frog in Temurung, 8. Change is a necessity, Ha Na Ca Ra Ka Da Ta Sa Wa La Pa Dha Ja Yes His Ma Ga Ba Tha Nga).

\section{CONCLUSION}

Channels of mass communication in instilling the values of Javanese philosophy into the roots of society through a variety of channels, one of which is able to attract the masses through puppet performances. The meaning behind the puppet show is a spectacle that serves as entertainment as well as being a picture and guide of life. Aside from being an entertaining spectacle, wayang art also holds philosophical meaning. Other channels which are a process of mass communication are also found in both written and unwritten teachings. From the writings of literature began to open teachings given and used for the provision of social life, the next development was made books produced by historical scavengers, scavengers of teachings, which had been written on rocks, leaves, or cave walls so that from literary tinulis become Literature Cetha From this beginning people saw 
that knowledge became a source of knowledge that continues to be developed so that it becomes science.

Javanese philosophical values embedded in the roots of the community are valuable capital used in the implementation of covid 19 management and implementation of SDGs because these values are very appropriate and have long rooted in the practice of people's daily lives. Only a policy is needed to revive the values of Javanese philosophy so that it can be implemented as a covid handler 19 policy and SDGs implementation.

\section{REFERENCES}

Budiardjo, Miriam, 2008, Dasar-Dasar Ilmu Politik. PT Gramedia Pustaka Utama, Jakarta. Easton, David, 1965, A System Analysis of Political Life. John Wiley and Sons, New York. Easton, David, 1971, The Political System, ed. Ke-2. Alfred A. knopf, Inc., New York.

Hendri, Dimas, 2008, Serat Tripama: Ajaran Luhur tentang Keprajuritan, Kebangsaan, dan Keteladanan, P_idea, Yogyakarta.

Kresna, Ardian, 2012, Dunia Semar, DIVA Press, Yogyakarta.

Laswel, Harold D., 1959, Who Gets What, When, How. Meridian Books Inc., New York.

Lipset, Seymour Martin, 1969, Political Man: The Social Bases of Politics. Vakils, Feffer dan Simons Private Ltd, Bombay.

M.Mclver, Robert, 1961, The Web of Government. The Macmillan Company, New York.

Nakamura, Robert. T, \& F. Smallwood, 1980, The Politics of Policy Implementation, St. Martin Press, New York.

Nugroho, Riant, 2012, Public Policy For The Developing Countries, Pustaka Pelajar, Yogyakarta.

Nugroho, Riant, 2012, Social Policy, Pustaka Pelajar, Yogyakarta.

Nugroho, Riant, 2013, National Security Policy : Sebuah Pengantar. Pustaka Pelajar, Yogyakarta.

Soltau, Roger F., 1961, An Introduction to Politics. Longmans, London.

Supardi, Imam, 1961, Hastha Brata: Piwulange Sri Rama marang Gunawan WIbisana sarta Larasane Tumrap Jaman Manipol, Panyebar Semangat, Surabaya.

Supardi, Imam, 1961, Sastra Djendrahayuningrat, Panyebar Semangat, Surabaya.

Suyami, 2008, Unsur Mistik dalam Serat Primbon, Kepel Press, Yogyakarta.

Syafiie, Inu Kencana, 2010, Pengantar Filsafat, Refika Aditama, Bandung.

Werdoyo, Yudo Wiryo, 2013, Sastra Carita menjadi Sastra Cetha, Kepel Press, Yogyakarta.

Wibawa, Samudra, 2011, Politik Perumusan Kebijakan Publik. Graha Ilmu, Yogyakarta. 